\title{
The effect of Georgia's HOPE scholarship on college major: a focus on STEM
}

\author{
David L Sjoquist ${ }^{1}$ and John V Winters ${ }^{2,3^{*}}$
}

\author{
* Correspondence: jvwinte@okstate. \\ edu \\ ${ }^{2}$ Spears School of Business, \\ Oklahoma State University, 331 \\ Business Building, Stillwater, OK \\ 74078-4011, USA \\ ${ }^{3}$ IZA, Bonn, Germany \\ Full list of author information is \\ available at the end of the article
}

\begin{abstract}
There is growing concern that the U.S. is producing too few college graduates in science, technology, engineering, and mathematics (STEM) fields, and there is a desire to understand how various policies affect college major decisions. This paper uses student administrative records from the University System of Georgia to examine whether and how Georgia's HOPE Scholarship has affected students' college major decisions, with a focus on STEM. We find that HOPE reduced the likelihood of earning a STEM degree. The research is complementary to a forthcoming paper by the authors, but using USG administrative records allows us to address several additional issues beyond the effect of merit aid on the likelihood of earning a STEM degree, including: the effect on initial major, earned major, and the transition between them; the roles of student ability, student performance, and institutional choice; and other possible mechanisms through which merit aid affects STEM education.
\end{abstract}

JEL codes: $123, \mathrm{~J} 24$

Keywords: Merit aid; HOPE scholarship; College major; STEM

\section{Introduction}

There is a substantial literature spanning several disciplines that attempts to explain students' choice of and persistence in a college major. More recently, this literature has focused on majors in science, technology, engineering, and math (STEM). The literature from education focuses on factors such as role models (including parents, teachers, and peers), exposure to math and science courses, and math self-efficacy beliefs; Delaney (2007), Crisp et al. (2009) and Wang (2012) provide surveys of the education literature.

Economists have also explored this issue. In a life-cycle utility maximization framework a student's choice of major depends on the student's preferences, the cost of completing various majors, the student's ability, that is, the probability of successfully completing the course of study for various majors, and the expected earnings after graduation (Berger 1988). Montmarquette et al. (2002) extend the model to include uncertainty regarding the successful completing of each major. While the cost of college has been shown to affect the probability of attending college, it has also been found to affect the choice of major; see for example, Stater (2011), Denning and Turley (2013), and Stange (2013). See Arcidiacono (2004), Kinsler and Pavan (2013), Griffith 
(2010), Beffy et al. (2012), Arcidiacono et al. (2012), and Wiswall and Zafar (2011) for other economic studies of the choice of college major.

We consider how Georgia's merit-based financial aid program, i.e., the HOPE Scholarship, affects student decisions to major in STEM fields. State merit aid programs have grown substantially since the early 1990s, with Georgia's HOPE Scholarship program adopted in 1993 being among the largest and most notable. ${ }^{1}$ A large research literature has emerged that examines the effects of these merit aid programs on college outcomes such as enrollment, persistence, completion, and post-college retention in the state. ${ }^{2}$ One outcome receiving limited attention thus far is the effect of merit aid on college major decisions.

We identified three studies that examine the effects of state merit aid programs on college majors. Cornwell et al. (2008) investigate the effect of Georgia's HOPE Scholarship on the college major choices of freshmen enrolled at the University of Georgia. They find that HOPE significantly increased the probability of majoring in education but find no significant effect of HOPE on other majors. The current paper differs from theirs in two major ways. First, our administrative data includes all 35 public colleges and universities in Georgia, not just one university as with Cornwell et al. (2008). Furthermore, we consider not just freshman major but also the major upon graduation.

Zhang (2011) examines the effects of merit aid programs in Florida and Georgia on annual statewide STEM degree conferrals computed from the Integrated Postsecondary Education Data System's (IPEDS) Completion Survey. He generally finds statistically insignificant effects of merit aid on the percentage of STEM graduates in each state, with the one exception being a 1.6 percentage point increase for Florida private institutions. However, merit aid programs likely affect where students attend college and have been shown to increase the average academic ability of students in the state. STEM fields require greater academic ability, especially in math, so merit-induced increases in average student quality need to be accounted for, but using aggregate data prevents Zhang from doing so.

Sjoquist and Winters (forthcoming) use American Community Survey (ACS) microdata to examine the average effects of merit aid programs across 25 states adopting them since 1991. Their analysis focuses on nine states with relatively large and generous merit aid programs and uses a difference-in-differences (DD) approach, comparing states with and without merit aid programs pre- and post-merit aid adoption. They find that the merit programs in these states substantially reduced the likelihood that an individual earned a degree in a STEM field. Their baseline estimate suggests that strong merit programs reduce the likelihood of earning a STEM degree by 1.3 percentage points (which corresponds to a 6.5 percent decrease in the number of STEM graduates), but alternative specifications suggest that the magnitude could be larger.

In this paper we use administrative records from the University System of Georgia (USG) to first examine the effect of Georgia's HOPE Scholarship on students' college major choices, focusing on STEM majors. We use a pre- and post-policy time difference identification strategy to estimate the model. Our analysis complements that of Sjoquist and Winters (forthcoming), but the current paper differs from Sjoquist and Winters in several ways. Examining USG administrative data allows us to explore the roles played by factors such as student ability, student performance in college, the transition between initial major and major at graduation, and how the effect on major 
differs by type of college. Using USG administrative data also offers a more precise measure of treatment than with the ACS, which requires defining treatment based on being born in a state with a merit-aid program at the time the student should have graduated from high school. Finally, Georgia's HOPE Scholarship is one of the largest and most generous merit aid programs in the nation, and it could have stronger effects than the average effect of the nine strong merit aid programs estimated by Sjoquist and Winters (forthcoming).

To preview our results, we find consistent evidence that Georgia's HOPE Scholarship reduced the probability that a young person would complete a bachelor's degree with a major in a STEM field. Our baseline specification yields an estimate of a 12.6 percent decrease in the number of STEM graduates, with the effects being larger for males than females. This estimate is larger than that found by Sjoquist and Winters (forthcoming) for their baseline specification, possibly because HOPE is an especially large merit program. The USG data include detailed student information that allows us to take a closer look at this effect than was possible with the ACS data used by Sjoquist and Winters. We are able to consider initial (freshman) major and find that HOPE had no statistically significant effect on the probability of being an initial STEM major for our preferred specification. For earned major we find no effect of HOPE on the probability of being a STEM major if we do not control for student quality; the ability to control for SAT score is thus an important feature of our data. We are able to document that the decline in earned STEM majors due to HOPE is primarily a result of initial STEM majors switching to another major and not a reduction in non-STEM majors who switch to being a STEM major. HOPE also had heterogeneous effects on the likelihood of specific non-STEM majors; we are also able to explore the effect of HOPE on the transition from an initial STEM major to a non-STEM major. We explore the effect of HOPE on the joint probability of graduating from college and being a STEM major and find an effect similar to earned STEM major conditional on graduating. The effect of HOPE on the likelihood of being a STEM major differs by type of initial college; we find no effect of HOPE for students starting in two-year colleges and a larger negative effect for students starting in one of the four research universities. We estimate the effect of HOPE by ability and find that the relative effects on the likelihood of earning a STEM major were most pronounced for students with good but unexceptional math skills.

There are several possible mechanisms through which HOPE could reduce the probability of earning a STEM degree. Unlike the ACS data, the USG data allow us to present some insights into some of these mechanisms; we discuss these mechanisms more fully in section 5. First, financial aid reduces the cost of tuition but not the other costs. To the extent that other costs differ across majors, financial aid changes the relative prices of majors, which could affect a student's choice of major. ${ }^{3}$ Second, financial aid reduces the need for a student to take out loans. The magnitude of a student's loans might affect the student's major if the student plans to choose an occupation that would allow him to pay off the debt quickly. Third, the mechanism that is perhaps most intuitive are student actions to maintain eligibility for HOPE, and in particular students might select or switch to a major for which it is easier to maintain a 3.0 GPA required to maintain HOPE. ${ }^{4}$ Fourth, the high school GPA requirements for merit aid eligibility may create incentives for students to enroll in less challenging courses in high 
school, which might make them less prepared for more difficult majors in college. Fifth, HOPE has been shown to alter the type of in-state institution students attend and to increase the likelihood that students stay in-state to attend college. This could affect the college major opportunities that are available and alter the relative attractiveness of specific majors. Our data do not allow us to identify the mechanisms driving the effect of HOPE on STEM majors, but we do offer some evidence for or against specific mechanisms.

\section{Data and empirical framework}

We explore the effects of the Georgia HOPE Scholarship on college major using administrative data for the University System of Georgia (USG). The USG is a statewide system that at the time consisted of 35 public higher education institutions including two- and four-year colleges and universities in Georgia. From the USG Board of Regents we obtained data on four cohorts of entering students to the USG. The four cohorts include all students who graduated from a Georgia high school during the years 1990, 1991, 1995 and 1996 and enrolled in a USG institution in the same year (i.e., students who enrolled in the summer or fall terms immediately after graduating high school). Data were obtained for the 1995 and 1996 cohorts instead of the 1993 and 1994 cohorts because these first two post-HOPE cohorts were initially subject to an income cap for eligibility. The 1992 cohort of students was avoided out of concern that some of these students might have anticipated the passage of HOPE and altered their behavior in response. The 1990-1991 cohorts are therefore the pre-HOPE control group and the 1995-1996 cohorts are the post-HOPE treatment group. ${ }^{5}$

The USG sample is also restricted to Georgia residents who graduated high school in Georgia because non-residents and graduates of schools outside of Georgia were not eligible for HOPE. Of particular importance, we know the major declared as a freshman and the earned major upon graduation. Our main sample is restricted to students who eventually earn a bachelor's degree from the USG. We first consider the effect of HOPE on majoring in a STEM field, and then consider the effects on other broad majors. Descriptive statistics by sex and pre- and post-HOPE are presented in Table 1.

We estimate a linear probability model as follows:

$$
P\left(Y_{i t}=1\right)=\beta X_{i t}+\theta \text { PostHOPE } E_{t}
$$

where $Y$ is an indicator variable equal to one if the individual's major is in a STEM field, ${ }^{6} X$ includes dummy variables for sex, race, Hispanic origin, high school attended, SAT score, and high school GPA, and PostHOPE is a dummy equal to one for the 1995-96 cohorts and zero for the 1990-91 cohorts. ${ }^{7}$ We used a set of GPA and SAT dummy variables since we did not want to assume that their effects are linear. ${ }^{8}$ Therefore, $\theta$ measures the effect of the HOPE program on the probability of being a STEM major holding student quality and demographics constant. We consider both the major at time of matriculation (initial major) and the final major (earned major). Sjoquist and Winters (2015) use the same preferred specification and confirm that there was no significant effect on degree completion in the USG dataset.

A concern with the use of these data is that HOPE could have affected the composition of the student body post-HOPE, resulting in a possible endogeneity problem. Dynarski (2000) and Cornwell et al. (2006), for example, find that the HOPE program 
Table 1 Summary statistics for USG data

\begin{tabular}{|c|c|c|c|c|c|c|c|c|c|c|c|}
\hline & \multicolumn{2}{|c|}{$\begin{array}{l}\text { All } \\
\text { graduates }\end{array}$} & \multicolumn{2}{|c|}{ Females } & \multicolumn{2}{|l|}{ Males } & \multicolumn{2}{|c|}{ Pre-HOPE } & \multicolumn{2}{|c|}{ Post-HOPE } & \multirow{2}{*}{$\begin{array}{l}\text { Difference } \\
\text { Pre/Post }\end{array}$} \\
\hline & Mean & S.D. & Mean & S.D. & Mean & S.D. & Mean & S.D. & Mean & S.D. & \\
\hline Initial STEM major & 0.197 & 0.398 & 0.148 & 0.355 & 0.262 & 0.440 & 0.184 & 0.387 & 0.208 & 0.406 & $0.025^{* * *}$ \\
\hline Earned STEM major & 0.197 & 0.398 & 0.128 & 0.334 & 0.289 & 0.453 & 0.201 & 0.400 & 0.193 & 0.395 & $-0.007^{*}$ \\
\hline Initial business major & 0.107 & 0.309 & 0.094 & 0.292 & 0.125 & 0.331 & 0.107 & 0.310 & 0.107 & 0.309 & 0.000 \\
\hline Initial education major & 0.044 & 0.206 & 0.066 & 0.248 & 0.016 & 0.125 & 0.042 & 0.200 & 0.047 & 0.211 & $0.005^{* *}$ \\
\hline Initial health major & 0.028 & 0.166 & 0.045 & 0.208 & 0.006 & 0.077 & 0.021 & 0.145 & 0.034 & 0.182 & $0.013^{* * *}$ \\
\hline Initial liberal arts major & 0.185 & 0.388 & 0.183 & 0.387 & 0.188 & 0.391 & 0.191 & 0.393 & 0.180 & 0.385 & $-0.010^{* * *}$ \\
\hline Initial social science major & 0.060 & 0.237 & 0.069 & 0.254 & 0.047 & 0.212 & 0.063 & 0.243 & 0.057 & 0.231 & $-0.006^{* * *}$ \\
\hline Initial undeclared major & 0.378 & 0.485 & 0.393 & 0.488 & 0.357 & 0.479 & 0.391 & 0.488 & 0.367 & 0.482 & $-0.024^{* * *}$ \\
\hline Earned business major & 0.261 & 0.439 & 0.213 & 0.410 & 0.324 & 0.468 & 0.241 & 0.428 & 0.278 & 0.448 & $0.037^{* * *}$ \\
\hline Earned education major & 0.153 & 0.360 & 0.216 & 0.412 & 0.068 & 0.252 & 0.171 & 0.376 & 0.138 & 0.345 & $-0.033^{* * *}$ \\
\hline Earned health major & 0.057 & 0.232 & 0.090 & 0.286 & 0.013 & 0.114 & 0.056 & 0.229 & 0.059 & 0.235 & 0.003 \\
\hline Earned liberal arts major & 0.157 & 0.364 & 0.155 & 0.362 & 0.160 & 0.367 & 0.151 & 0.358 & 0.163 & 0.369 & $0.011^{* * *}$ \\
\hline Earned social science major & 0.175 & 0.380 & 0.198 & 0.398 & 0.145 & 0.352 & 0.181 & 0.385 & 0.170 & 0.375 & $-0.012^{* * *}$ \\
\hline Post-HOPE dummy & 0.540 & 0.498 & 0.554 & 0.497 & 0.521 & 0.500 & & & & & \\
\hline SAT math & 518.4 & 92.8 & 498.9 & 85.8 & 544.3 & 95.4 & 513.1 & 89.8 & 523.0 & 95.1 & $9.953^{* * *}$ \\
\hline SAT verbal & 520.7 & 90.0 & 513.0 & 88.5 & 530.9 & 91.0 & 512.9 & 89.5 & 527.3 & 90.0 & $14.441^{* * *}$ \\
\hline High School GPA & 3.037 & 0.620 & 3.092 & 0.600 & 2.963 & 0.639 & 2.925 & 0.636 & 3.133 & 0.589 & $0.208^{* * *}$ \\
\hline emale & 0.572 & 0.495 & 1.000 & 0.000 & 0.000 & 0.000 & 0.555 & 0.497 & 0.587 & 0.492 & $0.032^{* * *}$ \\
\hline Black & 0.182 & 0.386 & 0.224 & 0.417 & 0.126 & 0.332 & 0.163 & 0.370 & 0.199 & 0.399 & $0.036^{* * *}$ \\
\hline Hispanic & 0.010 & 0.102 & 0.010 & 0.099 & 0.011 & 0.105 & 0.009 & 0.092 & 0.012 & 0.110 & $0.004^{* * *}$ \\
\hline Asian & 0.029 & 0.167 & 0.026 & 0.159 & 0.033 & 0.177 & 0.024 & 0.153 & 0.033 & 0.178 & $0.009^{* * *}$ \\
\hline Native American & 0.002 & 0.039 & 0.001 & 0.038 & 0.002 & 0.040 & 0.002 & 0.039 & 0.001 & 0.038 & 0.000 \\
\hline Observations & 42,399 & & 24,263 & & 18,136 & & 19,497 & & 22,902 & & \\
\hline
\end{tabular}

${ }^{*}$ significant at $10 \% ;{ }^{*}$ significant at $5 \% ;{ }^{* *}$ significant at $1 \%$

enticed students who would have gone to college out-of-state in the absence of HOPE to go to college in-state. Denote these students by $\mathrm{H}_{\mathrm{O}}$ and HOPE students who would have gone to college in-state without HOPE by $\mathrm{H}_{\mathrm{I}}$. (Obviously, we cannot identify which students are $\mathrm{H}_{\mathrm{O}}$ students.) If the $\mathrm{H}_{\mathrm{O}}$ students are equivalent to the $\mathrm{H}_{\mathrm{I}}$ students, then endogeneity should not be a problem. However, if $\mathrm{H}_{\mathrm{O}}$ students are less inclined to major in a STEM field, then our estimate of the effect of HOPE on STEM majors will be overstated. We control for the quality of students, which should reduce the importance of the endogeneity, although there may be unmeasured differences. On the other hand, if $\mathrm{H}_{\mathrm{O}}$ are more likely to be STEM majors than $\mathrm{H}_{\mathrm{I}}$ students, then we will underestimate the effect of HOPE on STEM majors. While we don't know which of these three alternatives is correct, we believe that $\mathrm{H}_{\mathrm{O}}$ students are not less likely to major in STEM than $\mathrm{H}_{\mathrm{I}}$ since the students who in the absence of HOPE would have gone to college out-of-state are likely to be higher quality students, and thus more likely to be STEM majors. ${ }^{9}$

There is some indirect support for this supposition. First, there is some evidence that the probability of being a STEM major is positively related to family income. For example, Moore (2014) finds that students from higher income families are more likely to major in STEM than low-income. ${ }^{10}$ Additionally, Jaquette et al. (2014) suggest that the 
probability that a student will attend an out-of-state school increases with family income. ${ }^{11}$ Sjoquist and Winters (2013) report that average SAT scores in the USG increased post-HOPE, and we find that STEM majors have higher average SAT scores. If the increase in SAT scores is due to higher-SAT students staying in-state for college as a result of HOPE, the implication is that these students are more likely to major in STEM. We also partially address this issue empirically below by examining the differential effects of HOPE on initial and earned STEM majors. If $\mathrm{H}_{\mathrm{O}}$ students have unobservables that less incline them toward STEM, the post-HOPE dummy should reduce both initial and earned STEM majors.

We are essentially estimating a time-differenced model. This raises identification concerns that the observed differences over time that we attribute to the effects of HOPE may be affected by other factors that vary over time and affect the probability of being a STEM major. As noted below, we address these concerns in several ways. We use ACS data that do not suffer problems from changes in student body composition to check the robustness of our basic results. We also use ACS data to confirm that other states did not experience a decrease in STEM during this time period that could confound our USG results. Finally, we explore using non-resident students in the USG as a control group. None of these alternatives suggest that HOPE did not cause a reduction in the likelihood that a student majors in STEM. These results are discussed in more detail below.

\section{The effects of HOPE on majoring in STEM}

In this section we present estimates of the effects of HOPE on the probability of being a STEM major. The USG data, unlike the ACS data used in Sjoquist and Winters (forthcoming), allow us to consider the effect of merit aid on both initial majors and earned majors, and to control for student quality. Note that the sample sizes for the main results are equivalent to those in Table 1. However, for several of the tables we consider various subsamples and there are multiple samples sizes, but we do not report these sample sizes. ${ }^{12}$

\subsection{Initial STEM major}

Columns 1-4 of Table 2 present the results for the USG analysis in which the dependent variable is whether a student initially declared a STEM major as a freshman. The first column includes dummies for sex, race, Hispanic origin, and high school attended, but not SAT, high school GPA, or institution. The second column adds SAT dummies, the third adds high school GPA dummies, and the fourth adds dummies for initial USG institution attended. There are important caveats for the last two columns. There is evidence of high school grade inflation for post-HOPE cohorts in Georgia. Appendix Table 14, which presents regressions of high school GPA for college graduates against a post-HOPE dummy using various controls, shows that high school GPA increased post-HOPE by 0.15 points for all majors and 0.11 points for STEM majors. ${ }^{13}$ Inflated high school GPAs for post-HOPE students mean that one should be cautious interpreting results that control for high school GPA because looking at students with the same GPA compares lower quality post-HOPE students to higher quality preHOPE students. ${ }^{14}$ Since student quality is positively correlated with the probability of majoring in a STEM field, grade inflation will create a negative bias in $\theta$ when controlling 
Table 2 Effects of HOPE on choosing a STEM major

\begin{tabular}{|c|c|c|c|c|c|c|c|c|}
\hline \multirow[t]{2}{*}{ 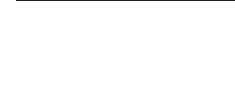 } & \multirow[t]{2}{*}{ (1) } & $(2)$ & (3) & (4) & \multirow[t]{2}{*}{ (5) } & (6) & (7) & \multirow[t]{2}{*}{ (8) } \\
\hline & & \multicolumn{3}{|c|}{ Initial major } & & \multicolumn{2}{|c|}{ Earned major } & \\
\hline \multirow[t]{3}{*}{ A. Total } & 0.0231 & -0.0048 & -0.0201 & 0.0086 & -0.0058 & -0.0253 & -0.0384 & -0.0216 \\
\hline & $(0.0080)^{*}$ & $(0.0059)$ & $(0.0042)^{* *}$ & $(0.0013)^{* * *}$ & $(0.0065)$ & $(0.0033)^{* * *}$ & $(0.0041)^{* * *}$ & $(0.0029)^{* * *}$ \\
\hline & $\{12.6 \%\}$ & $\{-2.6 \%\}$ & $\{-10.9 \%\}$ & $\{4.7 \%\}$ & $\{-2.9 \%\}$ & $\{-12.6 \%\}$ & $\{-19.1 \%\}$ & $\{-10.8 \%\}$ \\
\hline \multirow[t]{3}{*}{ B. Females } & 0.0284 & 0.0074 & -0.0046 & 0.0121 & 0.0041 & -0.0121 & -0.0240 & -0.0128 \\
\hline & $(0.0043)^{* * *}$ & $(0.0051)$ & $(0.0038)$ & $(0.0033)^{* *}$ & $(0.0050)$ & $(0.0048)^{*}$ & $(0.0049)^{* *}$ & $(0.0023)^{* *}$ \\
\hline & $\{21.8 \%\}$ & $\{5.7 \%\}$ & $\{-3.5 \%\}$ & $\{9.3 \%\}$ & $\{3.3 \%\}$ & $\{-9.8 \%\}$ & $\{-19.3 \%\}$ & $\{-10.3 \%\}$ \\
\hline \multirow[t]{3}{*}{ C. Males } & 0.0181 & -0.0182 & -0.0343 & 0.0065 & -0.0180 & -0.0416 & -0.0538 & -0.0321 \\
\hline & $(0.0162)$ & $(0.0086)$ & $(0.0075)^{* *}$ & $(0.0024)^{*}$ & $(0.0096)$ & $(0.0025)^{* * *}$ & $(0.0029)^{* * *}$ & $(0.0039)^{* * *}$ \\
\hline & $\{7.2 \%\}$ & $\{-7.3 \%\}$ & $\{-13.7 \%\}$ & $\{2.6 \%\}$ & $\{-6.1 \%\}$ & $\{-14.1 \%\}$ & $\{-18.2 \%\}$ & $\{-10.8 \%\}$ \\
\hline $\begin{array}{l}\text { Sex, race/ethnicity } \\
\text { dummies }\end{array}$ & Yes & Yes & Yes & Yes & Yes & Yes & Yes & Yes \\
\hline $\begin{array}{l}\text { High school } \\
\text { dummies }\end{array}$ & Yes & Yes & Yes & Yes & Yes & Yes & Yes & Yes \\
\hline SAT dummies & No & Yes & Yes & Yes & No & Yes & Yes & Yes \\
\hline $\begin{array}{l}\text { High school GPA } \\
\text { dummies }\end{array}$ & No & No & Yes & Yes & No & No & Yes & Yes \\
\hline $\begin{array}{l}\text { USG institution } \\
\text { dummies }\end{array}$ & No & No & No & Yes & No & No & No & Yes \\
\hline
\end{tabular}

for high school GPA. Furthermore, HOPE likely changed which institution students attend, and this may affect their majors. ${ }^{15}$ Our primary interest is in the overall effects of HOPE, but controlling for HOPE-induced changes in institution may partial out some of the effect. Our preferred estimates, therefore, do not control for high school GPA or institution, but we also report results that do. SAT score increases are likely to represent actual increases in student quality and should be controlled for, so our preferred specification is the second column that includes all of the controls except for high school GPA and institution. ${ }^{16}$

The results in the first column of Table 2 suggest that the HOPE Scholarship program increased the probability of declaring a STEM major as a freshman. The second column in which we control for student quality by adding the SAT score dummies results in a very small negative coefficient that is statistically insignificant. When we add the high school GPA dummies in the third column, the coefficient estimates increase in magnitude (i.e., become larger negatively) and become statistically significant. Adding institution dummies (column 4) turns the coefficient positive, and though relatively small it is statistically significant. However, we cluster by cohort, but there are only 4 cohorts, and we have only one state, so the clustered standard errors should be interpreted with some caution. ${ }^{17}$ The results for our preferred specification in column 2 suggest that, when controlling for changes in student quality using SAT scores, HOPE had no meaningful effect on the likelihood that freshmen declared a STEM major. ${ }^{18}$

\subsection{Earned STEM major}

Columns 5-8 of Table 2 report the effects of HOPE on the probability of earning a bachelor's degree in a STEM field. The coefficient on the post-HOPE dummy is statistically 
insignificant in column 5 , but the effect is significantly negative for all regressions in columns 6-8. For our preferred regression in column 6, the coefficient of -0.0253 implies that HOPE reduced the number of STEM graduates by 12.6 percent. Controlling for high school GPA again decreases the size of the coefficient. ${ }^{19}$ Controlling for institution again makes the coefficient smaller (i.e., less negative). If HOPE causes some students to go to college in state rather than out-of-state and if these students are more likely to major in STEM than other students, then the reported decrease in earned STEM majors is smaller than what would occur if there was no change in the composition of students.

Comparing columns 1 and 2 and 5 and 6 in Table 2 shows that including SAT makes the effect of HOPE on the probability of being a STEM major substantially more negative, both as a freshman and upon graduation. ${ }^{20}$ If HOPE resulted in higher-SAT students staying instate, controlling for SAT reduces some of the potential bias from the changing composition of the student body due to HOPE. Given the effect of SAT on the HOPE coefficient, a more casual analysis that does not control for SAT will find that HOPE had no effect on the probability of earning a STEM degree and not find a reduction in this probability due to HOPE because of the influx of high-ability students into the USG that was also due to HOPE.

Grades in STEM courses are lower than in other majors, which might reduce the likelihood that initial STEM majors eventually graduate relative to equal ability students not initially majoring in a STEM field. But that may not be the case for HOPE recipients. Furthermore, it is possible that HOPE could have altered the composition of college graduates by initial college major. Thus, we consider the effect of HOPE on degree completion for students with an initial STEM major (Table 3). ${ }^{21}$ The regressions suggest that HOPE had either no or a negative effect on graduation of initial STEM majors. For our preferred specification (column 2) the coefficients are negative but not statistically significant.

The pattern of coefficients by sex is also of interest. The coefficient for males is considerably larger than that for females, and the difference is statistically significant in columns 68. In column 6 the coefficient for males is -0.0416 , while the coefficient for females is only -0.0121 . The larger decrease for men is partially attributable to their higher prevalence in

Table 3 Effects of HOPE on degree completion for initial STEM majors

\begin{tabular}{lllll}
\hline & $(1)$ & $(2)$ & $(3)$ & $(4)$ \\
\hline A. Total & 0.0073 & -0.0135 & -0.0356 & -0.0336 \\
B. Females & $(0.0036)$ & $(0.0075)$ & $(0.0069)^{* *}$ & $(0.0067)^{* *}$ \\
& -0.0047 & -0.0184 & -0.0417 & -0.0350 \\
C. Males & $(0.0044)$ & $(0.0069)^{*}$ & $(0.0076)^{* *}$ & $(0.0079)^{* *}$ \\
& 0.0158 & -0.0121 & -0.0321 & -0.0317 \\
Sex, race/ethnicity dummies & $(0.0041)^{* *}$ & $(0.0068)$ & $(0.0060)^{* *}$ & $(0.0062)^{* *}$ \\
High school dummies & Yes & Yes & Yes & Yes \\
SAT dummies & Yes & Yes & Yes & Yes \\
High school GPA dummies & No & Yes & Yes & Yes \\
USG institution dummies & No & No & Yes & Yes \\
\hline
\end{tabular}

Standard errors in parentheses are clustered by high school graduation year *Significant at $10 \%$ based on small sample t-distribution; ** Significant at $5 \%$ 
STEM fields, but the relative magnitude for men is even greater than would be expected based on relative means. We also explored the effect of HOPE on subfields within STEM and found that the results reported above are not being driven by a particular subfield.

A possible concern with our results is that there may have been other policies that affected the choice of college major. We have surveyed policy changes that were adopted around the same time as HOPE and did not identify any policy that would be expected to change the choice of college major. Another important concern with attributing the pre- and post-HOPE differences to the merit program is that the economy could have experienced broader shifts over time that altered the relative desirability of STEM and non-STEM majors. Unfortunately, our administrative dataset includes only Georgia, and so we cannot estimate a difference-in-differences (DD) model to account for time differences in comparable states. We do, however, explore several alternatives.

We first used data from IPEDS on college major and do not observe any pre-HOPE downward trend in STEM majors in Georgia. We then explored separately including a linear time trend and the state unemployment rate in the regression model; ${ }^{22}$ doing so actually makes the negative coefficient on earning a STEM degree larger in magnitude, but including such variables is somewhat problematic with only four cohort years, so our preferred results exclude them. In addition, given that the size of the student body changed pre- and post-HOPE, we re-estimated the regression in column 6 of Table 2 using weights so that the pre- and post-HOPE periods are weighted equally. The results, which are not reported here, are qualitatively similar to those reported in Table 2 .

One possible control group for a DD estimator is non-resident USG students. Unfortunately, non-residents are an imperfect control group since HOPE could have created a variety of spillover effects onto non-residents, including changes in the composition of such students. Furthermore, among USG institutions, non-residents only enroll in large numbers at Georgia Institute of Technology (Georgia Tech) and the University of Georgia. Therefore, we cautiously explore the effects of HOPE on earning a STEM degree for students initially enrolling at these two institutions using both the residents-only time-differenced approach and a DD approach using non-residents as a control group; results are provided in Appendix Table 16. We further consider differences by initial institution type in a subsection below. The results in Table 16 show large negative effects of HOPE on earning a STEM degree using both approaches. The DD estimates are smaller and somewhat noisier, but possible spillover effects may render non-residents an inaccurate counterfactual.

We also examined American Community Survey (ACS) microdata to help assess whether earned college majors changed significantly over this time period in other states. The ACS reports earned college majors for bachelor's degree recipients, but it does not report initial college majors or majors for non-graduates. We use the 2009-13 ACS to construct a sample of college graduates who were age 18 in 1990, 1991, 1995, or 1996 and born outside of Georgia. Persons age 18 in 1990-91 and in 1995-96 likely finished high school at the same time as our pre- and post-HOPE USG cohorts, respectively. Thus, these ACS cohorts likely attended college and faced similar macroeconomic conditions as our USG cohorts, and their major decisions should have been affected similarly by any significant changes over this period. We then compute differences in the percentage of STEM graduates for the 1990-91 and 1995-96 ACS cohorts. In contrast to what we find in the USG, the percentage of STEM graduates for the ACS comparison group actually increased slightly over time for the rest of the U.S. and 
for Southern non-merit aid states. Additional details are available from the authors. These results support our contention that HOPE caused the observed negative effect on the probability of earning a STEM degree for Georgia resident USG graduates.

Sjoquist and Winters (forthcoming) use the 2009-11 ACS to estimate average treatment effects for the 9 states with strong merit programs. We also experimented with computing a difference-in-difference estimate for the specific effect of Georgia' HOPE Scholarship using the 2009-2013 ACS. Results are reported in Appendix Table 17. ${ }^{23}$ Unfortunately, examining ACS data for only one merit-adopting state produces noisy estimates, and the results are not statistically significant at the ten percent level. However, the coefficient estimates are negative and of similar magnitude to the estimates in Sjoquist and Winters (forthcoming) and not very different from our preferred estimates using the USG data in column 6 of Table 2.

\section{Additional issues}

The USG data allows us to explore several additional questions or issues that are not possible to consider with the ACS. In this section we consider these issues.

\subsection{Changing majors}

Our preferred specification in Table 2 suggests that the HOPE Scholarship did not affect the initial choice of a STEM major, but did negatively affect the probability of earning a STEM degree. We explore the relationship between the initial major and the earned major, considering just two categories of majors, STEM and non-STEM. The upper panel of Table 4 is a simple crosstab between initial major and earned major, while the second panel shows for each of the two initial majors the fraction of students with earned degrees with STEM and non-STEM majors. (Table 4 considers only students who earned a college degree but uses students from all 4 cohorts.) Note that 13.7 percent of students with an undeclared initial major earned a STEM degree, while only 8.4 percent of students who declared a non-STEM major as a freshman earned a degree with a STEM major. In other words, students who do not initially declare a STEM major have a relatively low probability of eventually earning a STEM degree. On the other hand, 57.4 percent of students with an initial STEM major actually earned a STEM degree, so that 42.6 percent of freshmen STEM majors switched to another major before they graduated. ${ }^{24}$

Table 4 Share of USG graduates by initial major and degree major

\begin{tabular}{|c|c|c|c|c|c|}
\hline & & \multicolumn{4}{|c|}{ Initial Major } \\
\hline & & Undeclared & Non-STEM & STEM & Total \\
\hline Degree & Non-STEM & 0.342 & 0.381 & 0.080 & 0.803 \\
\hline \multirow[t]{2}{*}{ Major } & STEM & 0.054 & 0.035 & 0.108 & 0.197 \\
\hline & Total & 0.397 & 0.416 & 0.188 & 1.000 \\
\hline Degree & Non-STEM & 0.863 & 0.916 & 0.426 & \\
\hline \multirow[t]{2}{*}{ Major } & STEM & 0.137 & 0.084 & 0.574 & \\
\hline & Total & 1.000 & 1.000 & 1.000 & \\
\hline
\end{tabular}

Note that Initial Major is the major the student declared as a freshman, while Degree Major is the major that the student graduated with. The table includes only students who completed college. The upper panel shows the distribution across all graduates, while the second panel shows the allocation across Degree Major for each Initial Major. The data include both pre- and post-HOPE students 
Given this pattern it is of interest to consider the effect of the HOPE Scholarship on the student's earned major given the student's initial major (Table 5). Column 1 of Table 5 reproduces column 6 from Table 2, and is presented for convenience. Column 2 considers students who declared a STEM major as a freshman. The results imply, as we would expect, that the HOPE Scholarship caused a reduction in the percentage of initial STEM majors who earned a degree in a STEM field. The coefficients are statistically significant for the entire sample as well as for females and males. The magnitude of the effect of the HOPE Scholarship is larger for initial STEM majors than for the entire sample (column 1) and is larger for males than females.

Columns 3 and 4 examine the effects of HOPE on earning a STEM degree for students with an initial non-STEM major and with an initial undeclared major. For these two groups, the coefficient estimates are negative for the total population as well as for females and males separately, but the coefficients are much smaller in magnitude than for initial STEM majors and are not statistically significant. Thus, the negative effect of HOPE on STEM degree production is primarily driven by initial STEM majors deciding not to complete degrees in STEM fields. HOPE is somehow causing additional initial STEM majors to switch away from STEM at some point before they graduate.

\subsection{Type of college}

The University System of Georgia consists of both 2-year and 4-year schools. One might expect that the effect of merit aid would differ between 2-year and 4-year institutions, perhaps because of differences in the type of students who enroll in the two types of schools, so we consider 2-year and 4-year colleges separately. Similarly, there are three large research universities, Georgia Institute of Technology, Georgia State University, and the University of Georgia. Given that the culture and other characteristics of large research universities might

Table 5 Effects of HOPE on earning a STEM degree by initial major

\begin{tabular}{lllll}
\hline & $(1)$ & $(2)$ & $(3)$ & $(4)$ \\
& Full & Initial STEM & $\begin{array}{l}\text { Initial non-STEM } \\
\text { majors }\end{array}$ & $\begin{array}{l}\text { Initial undeclared } \\
\text { majors }\end{array}$ \\
\hline A. Total & -0.0253 & -0.0788 & -0.0098 & -0.0085 \\
& $(0.0033)^{* * *}$ & $(0.0151)^{* *}$ & $(0.0075)$ & $(0.0044)$ \\
& $\{-12.6 \%\}$ & $\{-12.5 \%\}$ & $\{-11.5 \%\}$ & $\{-6.3 \%\}$ \\
B. Females & -0.0121 & -0.0633 & -0.0081 & -0.0053 \\
& $(0.0048)^{*}$ & $(0.0163)^{* *}$ & $(0.0040)$ & $(0.0047)$ \\
& $\{-9.8 \%\}$ & $\{-12.7 \%\}$ & $\{-15.3 \%\}$ & $\{-5.9 \%\}$ \\
C. Males & -0.0416 & -0.0937 & -0.0110 & -0.0138 \\
& $(0.0025)^{* * *}$ & $(0.0252)^{* *}$ & $(0.0162)$ & $(0.0062)$ \\
Sex, race/ethnicity dummies & $\{-14.1 \%\}$ & $\{-13.1 \%\}$ & $\{-8.2 \%\}$ & $\{-7.0 \%\}$ \\
High school dummies & Yes & Yes & Yes & Yes \\
SAT dummies & Yes & Yes & Yes & Yes \\
High school GPA dummies & Yes & Yes & Yes & Yes \\
USG institution dummies & No & No & No & No \\
\hline
\end{tabular}

Standard errors in parentheses are clustered by high school graduation year. The percent change, i.e., the coefficient divided by the mean, are shown in braces

*Significant at $10 \%$ based on small sample t-distribution; ${ }^{*}$ Significant at $5 \%$; ${ }^{* *}$ Significant at $1 \%$ 
differ from smaller 4-year colleges, we explore whether there are differences in the effect of HOPE on STEM majors between 4-year non-research colleges and the three research universities. In addition, the Georgia Institute of Technology is the primary engineering school in the University System of Georgia; Georgia Tech accounted for 32.6 percent of STEM degrees in the sample. Given the difference in the environment in an engineering college, we consider the effect of HOPE on STEM majors at Georgia Tech. We assign the student to the school at which they initially enrolled and use the control variables in our preferred specification.

Table 6 considers the effect of HOPE on the probability of earning a STEM degree by type of school. The results for all schools and for just 4-year schools are very similar, and in particular the effect of HOPE is negative. For 4-year non-research schools, the three research universities, and for Georgia Tech, the coefficients for HOPE for all students and for males are negative and statistically significant, but the magnitude of the effect is much larger for Georgia Tech and somewhat larger for the research universities than for the 4-year nonresearch schools. The coefficient for females is statistically insignificant in column 3, but negative and statistically significant in columns 4 and 5 . It thus appears that the effect of HOPE on the probability of being a STEM major is greater at research universities, and GA Tech in particular. ${ }^{25}$ In results not shown, we also estimated the effect of the post-HOPE dummy on earning a STEM degree for students initially enrolling at two-year schools. The coefficient was positive but small, noisily estimated, and potentially affected by student resorting across institution types post-HOPE.

\subsection{STEM persistence by SAT}

There is a substantial literature that attempts to explain the choice of a STEM major and the lack of persistence in earning a degree with a STEM major. The research reports that

Table 6 Effects of HOPE on earning a STEM degree by students' initial institutions

\begin{tabular}{llllll}
\hline & $(1)$ & $(2)$ & $(3)$ & $(4)$ & $(5)$ \\
& Full & 4 -Year & 4-Year & Research & Georgia \\
& USG & schools & non-research & universities & Tech \\
\hline A. Total & -0.0253 & -0.0284 & -0.0121 & -0.0588 & -0.0944 \\
& $(0.0033)^{* * *}$ & $(0.0036)^{* * *}$ & $(0.0033)^{* *}$ & $(0.0084)^{* * *}$ & $(0.0152)^{* * *}$ \\
& $\{-12.6 \%\}$ & $\{-13.7 \%\}$ & $\{-7.5 \%\}$ & $\{-20.6 \%\}$ & $\{-13.4 \%\}$ \\
B. Females & -0.0121 & -0.0145 & 0.0015 & -0.0442 & -0.1468 \\
& $(0.0048)^{*}$ & $(0.0048)^{*}$ & $(0.0026)$ & $(0.0093)^{* *}$ & $(0.0045)^{* * *}$ \\
& $\{-9.8 \%\}$ & $\{-11.2 \%\}$ & $\{1.5 \%\}$ & $\{-23.0 \%\}$ & $\{-23.4 \%\}$ \\
C. Males & -0.0416 & -0.0455 & -0.0331 & -0.0679 & -0.0762 \\
& $(0.0025)^{* * *}$ & $(0.0027)^{* * *}$ & $(0.0061)^{* *}$ & $(0.0096)^{* * *}$ & $(0.0171)^{* *}$ \\
Sex, race/ethnicity dummies & $\{-14.1 \%\}$ & $\{-14.9 \%\}$ & $\{-13.1 \%\}$ & $\{-18.1 \%\}$ & $\{-10.3 \%\}$ \\
High school dummies & Yes & Yes & Yes & Yes & Yes \\
SAT dummies & Yes & Yes & Yes & Yes & Yes \\
High school GPA dummies & Yes & Yes & Yes & Yes & Yes \\
USG institution dummies & No & No & No & No & No \\
\hline
\end{tabular}

Standard errors in parentheses are clustered by high school graduation year. The percent change, i.e., the coefficient divided by the mean, are shown in braces

*Significant at $10 \%$ based on small sample t-distribution; ${ }^{*}$ Significant at $5 \%$; ${ }^{* * *}$ Significant at $1 \%$ 
students with stronger academic ability as measured, for example, by SAT scores are more likely to initially major in a STEM field and to persist (Ost, 2010; Rask, 2010; Griffith, 2010). Here we consider the effect of HOPE on earned STEM degrees for initial STEM majors by SAT math score using our preferred specification.

Table 7 presents the results by SAT math score ${ }^{26}$ for each panel, the first row is the coefficient on the post-HOPE dummy, the second row in parentheses is the standard error, the third row in braces is the implied percentage change in STEM degrees, that is, the coefficient divided by the sample mean for the SAT group. ${ }^{27}$ The coefficients on the post-HOPE dummy are generally negative and are statistically significant for higher SAT math scores. HOPE reduced the probability that an initial STEM major would have an earned STEM degree, and the percentage of initial STEM major students who fail to get a STEM degree due to HOPE is smaller for higher SAT score students. This is not unexpected given existing research that finds that students with higher SAT scores are more likely to initially major in STEM and are more likely to persist and earn a STEM degree. Thus, we expect these students to be less influenced by HOPE. However, while we observe the same pattern for males, for females the relationship is reversed, with the larger percentage change being for females with high SAT math scores. ${ }^{28}$ It should be of concern for policymakers that HOPE appears to reduce the probability of earning a STEM degree even for students with high SAT math scores. ${ }^{29}$

\subsection{Non-STEM majors}

Table 8 considers the effects of the post-HOPE dummy on initial non-STEM majors. The only statistically significant coefficients are for health (positive coefficients) and social sciences (negative coefficients). It is unclear a priori why HOPE would affect these

Table 7 Effects of HOPE on earning a STEM degree by SAT math score for initial STEM majors

\begin{tabular}{llllll}
\hline \multirow{2}{*}{ SAT math } & $(1)$ & $(2)$ & $(3)$ & $(4)$ & $(5)$ \\
\hline A. Total & $<400$ & $400-499$ & $500-599$ & $600-699$ & $700-800$ \\
\hline & -0.0295 & -0.0052 & -0.0678 & -0.0805 & -0.0585 \\
B. Females & $(0.0280)$ & $(0.0176)$ & $(0.0141)^{* *}$ & $(0.0238)^{* *}$ & $(0.0168)^{* *}$ \\
& $\{-8.57 \%\}$ & $\{-1.41 \%\}$ & $\{-12.24 \%\}$ & $\{-11.02 \%\}$ & $\{-6.49 \%\}$ \\
& 0.0157 & 0.0262 & -0.0321 & -0.0594 & -0.1134 \\
C. Males & $(0.1091)$ & $(0.0312)$ & $(0.0056)^{* *}$ & $(0.0234)^{*}$ & $(0.0588)$ \\
& $\{5.24 \%\}$ & $\{9.26 \%\}$ & $\{-7.02 \%\}$ & $\{-8.89 \%\}$ & $\{-11.80 \%\}$ \\
Sex, race/ethnicity dummies & -0.0128 & -0.0691 & -0.1169 & -0.0824 & -0.0409 \\
High school dummies & $(0.1790)$ & $(0.0621)$ & $(0.0278)^{* *}$ & $(0.0318)^{*}$ & $(0.0240)$ \\
SAT dummies & $\{-3.11 \%\}$ & $\{-14.44 \%\}$ & $\{-18.49 \%\}$ & $\{-10.86 \%\}$ & $\{-4.59 \%\}$ \\
High school GPA dummies & Yes & Yes & Yes & Yes & Yes \\
USG institution dummies & Yes & Yes & Yes & Yes & Yes \\
\hline
\end{tabular}

Standard errors in parentheses are clustered by high school graduation year. The percent change, i.e., the coefficient divided by the mean, are shown in braces

*Significant at $10 \%$ based on small sample t-distribution; ${ }^{* *}$ Significant at $5 \%$ 
Table 8 Post-HOPE effects on initial major for non-STEM fields

\begin{tabular}{lllllll}
\hline & $(1)$ & $(2)$ & $(3)$ & $(4)$ & $(5)$ & $(6)$ \\
& Business & Education & Health & Liberal arts & Social sciences & Undeclared \\
\hline A. Total & -0.0025 & 0.0039 & 0.0135 & 0.0048 & -0.0096 & -0.0038 \\
& $(0.0086)$ & $(0.0051)$ & $(0.0043)^{*}$ & $(0.0115)$ & $(0.0019)^{* *}$ & $(0.0255)$ \\
& $\{-2.3 \%\}$ & $\{9.4 \%\}$ & $\{63.1 \%\}$ & $\{2.5 \%\}$ & $\{-15.2 \%\}$ & $\{-1.0 \%\}$ \\
B. Females & -0.0104 & 0.0030 & 0.0197 & -0.0096 & -0.0134 & 0.0059 \\
& $(0.0088)$ & $(0.0071)$ & $(0.0058)^{* *}$ & $(0.0079)$ & $(0.0022)^{* * *}$ & $(0.0265)$ \\
& $\{-10.8 \%\}$ & $\{4.7 \%\}$ & $\{54.7 \%\}$ & $\{-4.9 \%\}$ & $\{-18.0 \%\}$ & $\{1.5 \%\}$ \\
C. Males & 0.0070 & 0.0054 & 0.0055 & 0.0228 & -0.0041 & -0.0186 \\
& $(0.0089)$ & $(0.0024)$ & $(0.0023)^{*}$ & $(0.0152)$ & $(0.0028)$ & $(0.0234)$ \\
Sex, race/ethnicity dummies & Yes & Yes & Yes & Yes & Yes & Yes \\
High school dummies & Yes & Yes & Yes & Yes & Yes & Yes \\
SAT dummies & Yes & Yes & Yes & Yes & Yes & Yes \\
High school GPA dummies & No & No & No & No & No & No \\
USG institution dummies & No & No & No & No & No & No \\
\hline
\end{tabular}

Standard errors in parentheses are clustered by high school graduation year. The percent change, i.e., the coefficient divided by the mean, are shown in braces

*Significant at $10 \%$ based on small sample t-distribution; * Significant at 5\%

initial majors in this way. To some extent, the growth in health majors may reflect new programs created to meet the growing demand for healthcare.

Table 9 considers the effects of the post-HOPE dummy on earned non-STEM majors; the upper panel considers all students, while the lower panel considers just initial STEM majors. For the full sample, the post-HOPE period exhibits an increase in the probability of majoring in business and in health and a decrease in education and social science majors. ${ }^{30}$ The coefficient on the post-HOPE dummy for liberal arts majors is positive but statistically insignificant. There are differences in the pattern by gender.

The bottom panel of Table 9 contains results using just those students who declared a STEM major as a freshman. These results suggests that initial STEM majors who changed major likely shifted into business and liberal arts, although there are differences in the patterns by gender.

Cornwell et al. (2008), using data from the University of Georgia, find that HOPE led to an increase in the probability of an initial education major. We also find a positive but statistically insignificant effect on initial education major (Table 8). This leads to an expectation that merit-aid programs would also increase the probability of an earned major in education, but we find that merit aid reduces the probability of an earned major in education. To explore this a bit further, we redid our analysis using just data for the University of Georgia and find that HOPE had no effect on the probability of an earned major in education. When we consider the initial education major for University of Georgia students, we obtain a positive, but statistically insignificant, coefficient on HOPE that is similar in magnitude to that found by Cornwell et al. (2008). Thus, there may have been a slight positive effect of HOPE on initial education majors for students at the University of Georgia, but there appears to be no effect of HOPE on education degrees conferred. 
Table 9 Post-HOPE effects on non-STEM earned majors

\begin{tabular}{|c|c|c|c|c|c|}
\hline & (1) & $(2)$ & (3) & (4) & (5) \\
\hline & Business & Education & Health & Liberal arts & Social sciences \\
\hline \multirow[t]{3}{*}{ A. Total } & 0.0494 & -0.0282 & 0.0045 & 0.0101 & -0.0105 \\
\hline & $(0.0025)^{* * *}$ & $(0.0037)^{* * *}$ & $(0.0017)^{*}$ & $(0.0052)$ & $(0.0032)^{* *}$ \\
\hline & $\{20.5 \%\}$ & $\{-16.5 \%\}$ & $\{8.1 \%\}$ & $\{6.7 \%\}$ & $\{-5.8 \%\}$ \\
\hline \multirow[t]{3}{*}{ B. Females } & 0.0238 & -0.0417 & 0.0094 & 0.0163 & 0.0042 \\
\hline & $(0.0043)^{* *}$ & $(0.0052)^{* * *}$ & $(0.0022)^{* *}$ & $(0.0040)^{* *}$ & $(0.0014)^{*}$ \\
\hline & $\{12.0 \%\}$ & $\{-16.9 \%\}$ & $\{10.6 \%\}$ & $\{11.4 \%\}$ & $\{2.1 \%\}$ \\
\hline \multirow[t]{3}{*}{ C. Males } & 0.0797 & -0.0072 & -0.0013 & -0.0008 & -0.0288 \\
\hline & $(0.0063)^{* * *}$ & $(0.0026)^{*}$ & $(0.0009)$ & $(0.0068)$ & $(0.0062)^{* *}$ \\
\hline & $\{27.2 \%\}$ & $\{-9.6 \%\}$ & $\{-9.2 \%\}$ & $\{-0.5 \%\}$ & $\{-17.9 \%\}$ \\
\hline Sex, race/ethnicity dummies & Yes & Yes & Yes & Yes & Yes \\
\hline High school dummies & Yes & Yes & Yes & Yes & Yes \\
\hline SAT dummies & Yes & Yes & Yes & Yes & Yes \\
\hline High school GPA dummies & No & No & No & No & No \\
\hline USG institution dummies & No & No & No & No & No \\
\hline \multicolumn{6}{|l|}{ Initial STEM majors } \\
\hline \multirow[t]{3}{*}{ A. Total } & 0.0579 & -0.0015 & 0.0079 & 0.0121 & 0.0024 \\
\hline & $(0.0138)^{* *}$ & $(0.0043)$ & $(0.0048)$ & $(0.0039)^{*}$ & $(0.0038)$ \\
\hline & $\{42.8 \%\}$ & $\{-2.8 \%\}$ & $\{20.3 \%\}$ & $\{19.0 \%\}$ & $\{3.1 \%\}$ \\
\hline \multirow[t]{3}{*}{ B. Females } & 0.0334 & -0.0147 & 0.0134 & 0.0120 & 0.0192 \\
\hline & $(0.0160)$ & $(0.0071)$ & $(0.0156)$ & $(0.0015)^{* * *}$ & $(0.0106)$ \\
\hline & $\{25.5 \%\}$ & $\{-14.8 \%\}$ & $\{15.7 \%\}$ & $\{14.8 \%\}$ & $\{18.7 \%\}$ \\
\hline \multirow[t]{3}{*}{ C. Males } & 0.0768 & 0.0061 & 0.0033 & 0.0099 & -0.0024 \\
\hline & $(0.0222)^{* *}$ & $(0.0018)^{* *}$ & $(0.0011)^{*}$ & $(0.0091)$ & $(0.0030)$ \\
\hline & $\{55.7 \%\}$ & $\{25.1 \%\}$ & $\{42.4 \%\}$ & $\{19.0 \%\}$ & $\{-3.8 \%\}$ \\
\hline
\end{tabular}

Standard errors in parentheses are clustered by high school graduation year. The percent change, i.e., the coefficient divided by the mean, are shown in braces

*Significant at $10 \%$ based on small sample t-distribution; ${ }^{* *}$ Significant at $5 \%$; ${ }^{* * *}$ Significant at $1 \%$

\section{Mechanisms}

There are a number of possible mechanisms through which HOPE could reduce the probability of earning a STEM degree. We are able to offer evidence and insights for some of the possible mechanisms.

\subsection{Required 3.0 GPA}

Perhaps the most intuitive mechanism are student actions to maintain a 3.0 GPA in order to retain their HOPE Scholarship. Cornwell et al. $(2005,2008)$ suggest that the requirement that students maintain a 3.0 GPA causes students to engage in strategic behavior such as taking lighter course loads, easier courses, and changing majors if the student is close to a 3.0 GPA. This suggests that students might avoid majors for which maintaining a 3.0 GPA is harder, like STEM, when they first enter college. However, we see little effect of HOPE on choice of freshman major, which is inconsistent with this mechanism.

To examine this mechanism further we explore how the effect of HOPE differs by first-year GPA (for initial STEM majors), that is, after 45 quarter credit hours. ${ }^{31}$ 
The results are presented in Table 10. The coefficients on the HOPE variable are negative, with one exception, but less than half are statistically significant. There is no consistent pattern in the size of the coefficients on HOPE or the percentage change in the number of students who fail to earn a STEM degree because of HOPE. The results suggest that the HOPE Scholarship reduced the probability of an earned STEM major regardless of first-year GPA and that in general the magnitude of the effect does not depend on the first-year GPA. We do not find a larger effect of HOPE for students with a first-year GPA near 3.0, but some students may have already changed majors and others may have padded their first year schedule with easier courses. As Ost (2010) reports, grades both push students away from a major and pull them towards a major, and since first year grades are not necessarily in STEM courses, the effect by grade may reflect the pull of grades into non-STEM fields.

A further difficulty with using first year GPAs is that it appears that HOPE led to an increase in grades, which is consistent with students taking actions to improve their grades, and that the increase was larger for non-STEM majors than for STEM majors. Table 11 explores how the post-HOPE dummy affected students' first year GPAs, by category of majors. In general, the results imply that the HOPE Scholarship program increased students' GPAs, but the effects for initial STEM majors who earn STEM degrees are smaller than the effects for initial STEM majors earning degrees in other fields. This suggests that many of the latter group may have already begun taking a non-STEM curriculum. These results are consistent with the suggestion that students take actions to improve their grades in an attempt to meet HOPE's 3.0 GPA renewal requirement, although we cannot precisely assess the relative contribution of these student actions to the overall decrease in STEM. ${ }^{32}$ Although Table 10 parallels the format of Table 7, because college GPA is subject to various forms of manipulation, GPA cannot be viewed as an exogenous measure of student ability for our analysis as is the SAT score used in Table $7 .^{33}$

Table 10 Effects of HOPE on earning a STEM degree by first-year GPA for initial STEM majors

\begin{tabular}{lllllll}
\hline & $(1)$ & $(2)$ & $(3)$ & $(4)$ & $(5)$ & $(6)$ \\
Freshman GPA & $<2.50$ & $2.50-2.79$ & $2.80-2.99$ & $3.00-3.19$ & $3.20-3.49$ & $3.50-4.00$ \\
\hline A. Total & -0.0718 & -0.1449 & -0.0632 & -0.0878 & -0.0321 & -0.1027 \\
& $(0.0322)$ & $(0.0281)^{* *}$ & $(0.0563)$ & $(0.0131)^{* * *}$ & $(0.0143)$ & $(0.0139)^{* * *}$ \\
& $\{-14.75 \%\}$ & $\{-22.90 \%\}$ & $\{-10.01 \%\}$ & $\{-13.11 \%\}$ & $\{-4.47 \%\}$ & $\{-12.70 \%\}$ \\
B. Females & -0.0394 & -0.1306 & -0.1085 & -0.1629 & 0.0411 & -0.0704 \\
& $(0.0456)$ & $(0.0820)$ & $(0.0826)$ & $(0.0726)$ & $(0.0417)$ & $(0.0141)^{* *}$ \\
& $\{-11.07 \%\}$ & $\{-28.05 \%\}$ & $\{-20.56 \%\}$ & $\{-29.21 \%\}$ & $\{7.18 \%\}$ & $\{-9.73 \%\}$ \\
C. Males & -0.0858 & -0.1356 & -0.0483 & -0.0950 & -0.1114 & -0.1247 \\
& $(0.0404)$ & $(0.0568)^{*}$ & $(0.0658)$ & $(0.0148)^{* * *}$ & $(0.0308)^{* *}$ & $(0.0248)^{* *}$ \\
Sex, race/ethnicity dummies & Yes & Yes & Yes & Yes & Yes & Yes \\
High school dummies & Yes & Yes & Yes & Yes & Yes & Yes \\
SAT dummies & Yes & Yes & Yes & Yes & Yes & Yes \\
High school GPA dummies & No & No & No & No & No & No \\
USG institution dummies & No & No & No & No & No & No \\
\hline
\end{tabular}

Standard errors in parentheses are clustered by high school graduation year. The percent change, i.e., the coefficient divided by the mean, are shown in braces

*Significant at $10 \%$ based on small sample t-distribution; **Significant at $5 \%$; ***Significant at $1 \%$ 
Table 11 Effects of HOPE on first-year GPA

\begin{tabular}{|c|c|c|c|c|}
\hline & (1) & (2) & (3) & (4) \\
\hline & $\begin{array}{l}\text { All } \\
\text { graduates }\end{array}$ & $\begin{array}{l}\text { Initial STEM } \\
\text { majors }\end{array}$ & $\begin{array}{l}\text { Initial STEM majors earning } \\
\text { STEM degrees }\end{array}$ & $\begin{array}{l}\text { Initial STEM majors earning } \\
\text { non-STEM degrees }\end{array}$ \\
\hline \multirow[t]{2}{*}{ A. Total } & 0.1793 & 0.1290 & 0.1229 & 0.1847 \\
\hline & $(0.0119)^{* * *}$ & $(0.0120)^{* * *}$ & $(0.0201)^{* * *}$ & $(0.0106)^{* * *}$ \\
\hline \multirow[t]{2}{*}{ B. Females } & 0.1928 & 0.1467 & 0.1533 & 0.1672 \\
\hline & $(0.0118)^{* * *}$ & $(0.0247)^{* * *}$ & $(0.0345)^{* *}$ & $(0.0465)^{* *}$ \\
\hline \multirow[t]{2}{*}{ C. Males } & 0.1604 & 0.1074 & 0.0998 & 0.1823 \\
\hline & $(0.0146)^{* * *}$ & $(0.0129)^{* * *}$ & $(0.0272)^{* *}$ & $(0.0274)^{* * *}$ \\
\hline $\begin{array}{l}\text { Sex, race/ethnicity } \\
\text { dummies }\end{array}$ & Yes & Yes & Yes & Yes \\
\hline $\begin{array}{l}\text { High school } \\
\text { dummies }\end{array}$ & Yes & Yes & Yes & Yes \\
\hline SAT dummies & Yes & Yes & Yes & Yes \\
\hline $\begin{array}{l}\text { High school GPA } \\
\text { dummies }\end{array}$ & No & No & No & No \\
\hline $\begin{array}{l}\text { USG institution } \\
\text { dummies }\end{array}$ & No & No & No & No \\
\hline
\end{tabular}

Standard errors in parentheses are clustered by high school graduation year

** Significant at $5 \%$ based on small sample t-distribution; ${ }^{* *}$ Significant at $1 \%$

This mechanism is also consistent with our findings that HOPE did not have a negative effect on STEM majors of students who enrolled in two-year schools. Since grading standards at two-year schools are lower, students should have less concern with how a STEM major will affect their GPA.

\subsection{Costs and benefits of a major}

There are two possible mechanisms that relate to the effect of merit aid on the relative costs and benefits of a major. First, Stater (2011) argues that an increase in financial aid lowers the price of majors that offer current consumption benefits and encourages student substitution toward such majors and finds that merit aid affects the choice of the student's first-year major. ${ }^{34}$

Second, Rothstein and Rouse (2011) suggest that student loan debt might affect a student's choice of college major and future occupation due to debt aversion and credit constraints. Students who are debt averse may choose high earning majors and occupations to pay off debt quickly after graduation. Post-graduation credit constraints may make it difficult to finance large purchases like cars and houses, and individuals may pursue high earning majors and occupations to make these more attainable. Financial aid should decrease student loan debt and may reduce the importance of future earnings in college major decisions.

The mechanisms suggested by Stater (2011) and Rothstein and Rouse (2011) predict that financial aid will encourage students to shift away from high paying majors such as STEM fields, but the expected magnitudes are uncertain. Our findings for earned STEM majors are consistent with this mechanism. However, business majors also earn relatively high salaries, but we do not observe a shift away from business majors; we actually see a strong shift toward business. The large shift toward business is seemingly 
inconsistent with the mechanisms suggested by Stater (2011) and Rothstein and Rouse (2011). Additionally, their mechanisms would suggest a decrease in initial STEM majors, but we observe no such decrease in our preferred specification. So while we cannot rule out the Stater (2011) and Rothstein and Rouse (2011) mechanisms, they seem unlikely to be a significant explanation for the relatively large decrease in STEM degrees that we find.

\subsection{Change in enrollment patterns}

It is likely that the probability that a student earns a major in a STEM field differs across colleges. For example, Griffith (2010) finds that persistence of STEM majors varies inversely with the importance of research at the school. Webber (2012) reports that college completion is affected by a college's expenditures on student services and instruction, while Price (2010) finds that black students are more likely to persist in STEM majors if they have a course taught by a black professor. Luppino and Sander (2015) and Arcidiacono et al. (2013) provide evidence of peer competition effects in the University of California system; they find that attending a more competitive campus makes a student of a given quality less likely to earn a degree in the sciences.

In addition to these empirical findings, there are other possible reasons why the probability of earning a STEM major might differ across colleges. The strength of STEM fields can differ across colleges, making them more or less desirable majors. Grading standards in STEM fields likely differ across colleges so that maintaining the HOPE required 3.0 GPA could be easier at some colleges, thus affecting the likelihood that a student of a given quality majors in a STEM field or the likelihood that students shift to other majors. Colleges and departments can differ in the intensity of the advising and mentoring that students are provided, which can possibly influence a student's field of study and might affect the attachment to the field for initial STEM majors so that fewer students switch majors as a result of HOPE.

Thus, to the extent that HOPE affected the pattern of enrollment across colleges, the percent of students who earn a STEM major could have changed as a result. In fact, previous researchers (Dynarski, 2000; Cornwell et al. 2006) have found that merit aid increases the likelihood that students stay in-state to attend college and alters the type of in-state institution students attend.

While our preferred results in Table 2 do not control for institution (or high school GPA), adding institution dummies to our regressions in Table 2 makes the effect of HOPE more positive for both initial and earned STEM major outcomes. This change in the coefficients suggests that there are differences across colleges in the effect of HOPE on STEM majors. These results further suggest that some of the negative effect of HOPE on earned STEM degrees for our preferred specification is due to changes in the institutions that students attend. Specifically, it appears that HOPE induced students of a given academic ability to enroll in institutions that make them less likely to earn a STEM degree. This may have resulted in part from merit-induced increases in average student quality at top universities like Georgia Tech, which may have caused more moderate ability students to enroll elsewhere, as implied by the increased SAT scores at USG research universities. However, the movement toward institutions 
with weaker STEM programs could also be consistent with students enrolling at less competitive institutions to increase their chances of keeping a 3.0 GPA to retain HOPE.

\subsection{High school courses}

High school GPA requirements for merit aid eligibility may create incentives for students to enroll in less challenging courses in high school, which might make them less prepared for more difficult majors in college; alternatively, if merit programs increase student effort in high school, they could cause students to be better prepared for college, which is consistent with the findings of Henry and Rubenstein (2002). We have no evidence on high school course taking, but the high school grade inflation we observe is consistent with students taking easier courses in high school.

\subsection{Other explanations}

There are other potential explanations for why HOPE would reduce the likelihood of a STEM major, but which cannot be explored with our data. For example, students may initially select a STEM major on the basis of incomplete information regarding their interests in and the difficulty of the courses (Stinebrickner and Stinebrickner 2014). As they take STEM courses, the students update their information and may change their major. It is possible that the 3.0 GPA requirement for HOPE amplifies the belief updating process, perhaps causing some students to quit the STEM major prematurely. The effect of HOPE may be consistent with behavioral mechanisms such as loss aversion, hyperbolic discounting, and rules of thumb. According to the theory of loss aversion, people weigh potential losses much more heavily than potential gains when making choices under uncertainty. Thus, if students view the higher future earnings from a STEM degree as a gain and are sufficiently loss averse, their college major decisions will be much more affected by the prospect of losing HOPE than would be predicted by the lifetime utility model. Hyperbolic discounting suggests that some people make timeinconsistent choices because of preferences that heavily discount the future relative to the present. Hyperbolic discounting may affect students' decisions about their college major because losing HOPE has a present cost while the costs of switching to a lower earning major are born further in the future. Pallais (2015) suggests that instead of being rational lifetime income/utility maximizers, students may follow rules of thumb to make choices under uncertainty. The HOPE Scholarship 3.0 GPA renewal requirement may provide a rule of thumb for students about major choices; in particular, a student might think that if he cannot be a "good student" (as measured by the 3.0 minimum GPA) in a difficult major, then he should choose a less challenging major.

\subsection{Summary}

While we are unable to identify the mechanisms driving our results, we are able to provide evidence regarding some of the potential mechanisms. Specifically, we find evidence consistent with two mechanisms: students taking actions to increase their GPAs to retain HOPE and students enrolling at less competitive institutions that make them less likely to major in STEM. The policy implications differ somewhat depending on how important each of these mechanisms are. If student actions are the primary 
mechanism, policymakers should consider reducing the incentives to take such actions, perhaps by allowing the renewal GPA to differ by major and even institution. To the extent that the effect is driven by inelastic supply at selective universities, states with or considering adopting merit aid programs should be aware that the potential benefits may not be realized if their program crowds some students into less selective institutions with weaker STEM programs.

\section{Summary and conclusions}

State merit aid programs have grown significantly since the early 1990s, but these programs could have unintended effects that harm the economic interests of the state and the nation. In particular, merit programs may inadvertently cause students to choose different college majors than they would have in the absence of merit aid. The U.S. has experienced increasing concern that the nation is producing too few graduates with degrees in science, technology, engineering, and mathematics (STEM) fields. STEM graduates play an important role in creating new technologies that lead to new production processes and increased productivity (Winters, 2014a, b). Producing too few STEM graduates could have very harmful economic effects for the nation and individual states.

This paper uses student records from the University System of Georgia (USG) to examine whether Georgia's HOPE Scholarship program altered students' college major decisions. We focus on the effects on STEM fields but also examine the effects on other majors. We find significant evidence that HOPE reduced the likelihood that a young person earned a degree in a STEM field. Our baseline specification gives a coefficient of -0.025 , which corresponds to a 12.6 percent decrease in the number of STEM graduates. The effect of HOPE is in contrast to evidence from ACS data that the likelihood of an individual being a STEM major increased over the period in states without merit aid programs. We also find that although Georgia's HOPE Scholarship reduced STEM degree completion, it did not affect the likelihood that a student chose STEM as their initial major. Instead, HOPE appears to have resulted in some students to change majors out of STEM fields at some point in their college career. Furthermore, the decrease in STEM degrees was driven largely by the decrease in initial STEM majors actually earning a STEM degree (not by fewer students switching into a STEM field) and by the decrease in earned STEM degrees by students enrolled at the state's research universities. The decrease in STEM degrees also occurred throughout the ability distribution, but the relative effects were most pronounced for students with good but unexceptional math skills. Our finding that merit aid programs such as Georgia's HOPE Scholarship reduce the likelihood that students earn degrees in STEM fields has important policy implications for both states and the nation and should be considered in debates on the merits of merit programs.

\section{Endnotes}

${ }^{1}$ HOPE (Helping Outstanding Pupils Educationally) is a universal merit-based postsecondary scholarship and grant program for Georgia students enrolled in college or a technical school. To be eligible a student must be a U.S. citizen or eligible non-citizen, a Georgia resident, enrolled in an eligible institution (either full or part time), have a 3.0 GPA in high school, and maintain a GPA of 3.0 in college. For more details see Sjoquist and Walker (2010). As Sjoquist and Walker note, the motivation for HOPE was Governor Miller's desire 
to elevate the importance of education to Georgians. As best as we can determine, there were no other policies adopted at that time that might have affected student choice of major.

${ }^{2}$ Sjoquist and Winters $(2012,2015)$ find small and insignificant average effects of merit aid on college attendance and completion rates. Welch (2014) finds minimal effects of merit aid on persistence and degree completion for students at community colleges. Sjoquist and Winters (2014) find that on average merit aid does increase the percentage of college attendees residing in their native state post-college, but there are meaningful differences in the effects across states.

${ }^{3}$ Other researchers have found that relatively small changes in the total cost of college can significantly affect the choice of major. Denning and Turley (2013) explore the effects of the SMART Grant program on choice of major. The SMART program provided financial aid to college juniors and seniors majoring in STEM and foreign languages. They find that the SMART Grant program induced students to major and take courses in incentivized fields; a roughly 3 percentage point increase in Texas and a 10 percentage point increase at BYU. Stange (2013) studies the effects on the choice of major resulting from differential tuition across undergraduate majors and finds that differential tuition altered the allocation of students across majors.

${ }^{4}$ Dee and Jackson (1999) report that students majoring in science, engineering, and computing are significantly more likely to lose the Georgia HOPE scholarship than those in other majors, but do not examine how this might affect students college major choices.

${ }^{5}$ Appendix Table 12 shows how the composition of the student body changed preand post-HOPE.

${ }^{6}$ We follow the Sjoquist and Winters (forthcoming) definition of STEM majors based on the Immigration and Customs Enforcement list; see table A.1 in Sjoquist and Winters (forthcoming).

${ }^{7}$ Note that the post-HOPE dummy equals one for all students in the post-HOPE cohort and not just students who received the HOPE Scholarship. We do not have the HOPE GPA needed to determine if pre-HOPE students would have qualified for HOPE had it existed. The high school GPA calculated to determine HOPE eligibility is not the same GPA that USG schools use to determine whether to admit a student; we have the admission GPA for the pre-HOPE period and cannot calculate the HOPE GPA. However, 86 percent of our post-HOPE sample of graduates received HOPE as freshmen as did 92 percent of post-HOPE graduates with initial STEM majors, so the post-HOPE dummy is a reasonably good approximation for HOPE receipt. We also considered an event-style analysis by replacing the post-HOPE dummy with three dummies for matriculation year. Results, reported in Appendix Table 13, are qualitatively similar to using the simple post-HOPE dummy.

${ }^{8}$ Specifically, we define 13 groups for both math and verbal SAT scores and define a dummy variable for each (excluding the lowest as the base group). The groups are 200-340, 350-390, 400-430, 440-460, 470-490, 500-520, 530-550, 560-580, 590$610,620-650,660-690,700-750$, and 760-800. We control for math and verbal scores separately because they are expected to have differing effects on the probability of being a STEM major. We also define 26 high school GPA groups; students with GPA below 1.5 are the base group. We then round GPAs to the nearest tenth and include a dummy for each tenth, e.g., dummies for 1.6, 1.7, 1.8, ..., 3.9, and 4.0. 
${ }^{9}$ To explore the effect of the possible change in the student body due to HOPE we considered students from high schools for which the number of students attending USG schools changed by less than 5 percent pre- and post-HOPE and that did not change at all. The results for both groups are similar to our main results (Table 2), but because of the small sample size the coefficients are noisier.

${ }^{10}$ However, Stater (2011) finds that higher family income reduces the probability of being a science major.

${ }^{11}$ In addition, Kinsler and Pavan (2011) find that the probability that a student attends a high-quality college increases with family income. Fuller, Manski, and Wise (1982) find that high income households are less sensitive to the cost of college.

${ }^{12}$ Reporting sample sizes for each subsample would clutter the tables. The sizes of the various subsamples almost always exceed 1000; the exception is for Table 7 (results by SAT) for initial STEM majors in which there are only 356 female initial STEM majors with SAT math scores in the 700-800 range and only 839 male initial STEM majors with SAT math $<400$.

${ }^{13}$ Sjoquist and Winters (2013) also find evidence of high school grade inflation for the full population of students enrolled in the USG, i.e., the result is not unique to the sample of graduates. The increase in high school GPAs over time could also be partially attributable to factors other than HOPE. However, regardless of the source, grade inflation over time makes high school GPA a problematic control variable for our analysis.

${ }^{14}$ Castleman (2012) also finds that students in Florida take strategic actions to help ensure that their high school GPAs and SAT/ACT scores are above the cutoffs.

${ }^{15}$ If applicants perceive that admissions at selective institutions are becoming more competitive post-HOPE, they may report more challenging intended majors in order to bolster their chances of admission. However, the period that we consider is early in the life of the HOPE program, and it was not until later that admissions to some of the colleges became much more difficult. So we do not believe that perceived admission standards would have induced applicants to alter their reported major.

${ }^{16}$ Note that the SAT is not part of the HOPE eligibility condition and thus not subject to merit-induced strategic manipulation.

${ }^{17}$ In results not shown, we also experimented with several alternative procedures for estimating standard errors for our baseline results including individual OLS, individual bootstrapped, clustering by origin county, the Donald and Lang (2007) mean residual by cluster OLS standard error procedure, and a cluster-bootstrap procedure. Inferences are qualitatively consistent across the various standard error estimates.

${ }^{18}$ One limitation of the analysis using the initial major is that a very large percentage of students, almost 40 percent, do not have a declared major. This is much larger than the 19.9 percent reported by Stater (2011) for the three universities in Colorado, Indiana, and Oregon (1994-1996) and 29.5 percent reported by Carruthers and Ozek (2012) for 4-year schools in Tennessee. In results not shown, we examined using a dummy for "ever held a STEM major" as an outcome variable; results were similar to those using the initial STEM major dummy.

${ }^{19} \mathrm{We}$ also estimate regressions similar to those in columns 2 and 6 , but that include USG institution dummies. The coefficient on the post-HOPE variable becomes more positive (initial major) or less negative (earned major). We note that the changes in the coefficient when including USG institution dummies are very similar when the GPA 
dummies are included (compare columns 3 and 4 and columns 7 and 8) and when they are excluded.

${ }^{20}$ SAT scores increased over the period, but it is unclear if the increase represents real or inflationary changes. To assess possible bias due to SAT inflation, we rescaled SAT math and verbal scores by deflating them based on the ratios of mean scores by year for Georgia high school students published by the National Center for Education Statistics in the Digest of Education Statistics. Using the "deflated" SAT scores in our preferred specification for earned STEM majors (panel A column 6 of Table 2) attenuated the coefficient from -0.0253 to -0.0208 , but the difference is not statistically significant. Furthermore, if some of the increase in SAT scores was due to real increases in student aptitude, perhaps resulting from HOPE providing incentives to work harder in high school, then fully deflating will attenuate the coefficient more than it should. In summary, results are qualitatively robust to accounting for SAT score inflation.

${ }^{21}$ Appendix Table 15 presents results corresponding to the specifications in Table 2 that include the full sample of USG enrollees unconditional on eventual degree completion. Results are qualitatively similar to those in Table 2 .

${ }^{22}$ Over the period 1983 to 2000, the unemployment rate in Georgia decreased almost uniformly (1992 was the exception); the correlation between the unemployment rate and a time trend over this period is -0.84 . This strongly suggests that the unemployment rate did not have an effect separate from the time trend.

${ }^{23}$ Persons are assigned to the HOPE treatment group if they were born in Georgia and were age 18 in 1993 or later. Regression controls include dummies for year age 18, survey year, age, birth state, sex, race, and ethnicity. The control group includes persons born in states not adopting a merit aid program prior to 1998. We estimate the effects for 4-year, 5-year, and 6-year policy windows; an X-Year Window means that cohorts included were age $18 \mathrm{X}$ years before or after the policy was adopted. Including cohorts that are very far from the policy adoption weakens the identification since DD assumes a break right at policy adoption; using a 7- or 8-year window produces results similar to the 6-year window. However, examining a less than 4-year window is problematic because it yields few observations and focuses on treated observations in the very first post-HOPE cohorts. The 1993 and 1994 cohorts of entering freshmen were subject to an income cap for eligibility which reduced the percentage of Georgia students in these first cohorts who were affected by HOPE. Furthermore, focusing very close to the policy adoption exacerbates measurement error issues resulting from some students finishing high school at an age other than 18. Standard errors are clustered by year age 18, but significance levels are unchanged under several reasonable alternative inference procedures.

${ }^{24}$ See Stinebrickner and Stinebrickner (2014) for an analysis of the attrition of STEM majors. They focus on the effect of changes in students' beliefs about their likely grade point average as STEM majors as the students take STEM courses.

${ }^{25}$ This is consistent with arguments that the state's research universities have tougher grading standards than other institutions and may have increased grading standards in STEM fields post-HOPE. In results not shown, available from the authors by request, we also examined the effect of initial institution and initial major on the probability of keeping HOPE for four years for the sample of students who received HOPE as freshmen, controlling for students quality and individual characteristics. As one might 
expect, students starting at more selective institutions were less likely to keep HOPE for four years than comparable students starting at less selective institutions. Similarly, initial STEM majors were less likely to keep HOPE than comparable non-STEM majors.

${ }^{26} \mathrm{~A}$ few individuals do not have SAT scores. Examination of their GPAs shows that they are, on average, low performing students, so we include them in the lowest SAT group.

${ }^{27}$ Though not the focus of our study, the simple means are consistent with previous literature suggesting that STEM persistence rates increase with student ability and are generally lower for women than men.

${ }^{28}$ The large magnitude for females with high SAT math scores was not expected. One possible explanation is that this effect could be caused by an increase in female students at Georgia Tech, which as Table 4 shows had a larger effect on STEM majors. However, the increase in the percentage of female students at Georgia Tech pre- and post-HOPE was no larger than that experienced in the rest of the USG. Furthermore, the number of females with 700 or better SAT-Math scores is relatively small, so the coefficient is not precisely estimated.

${ }^{29}$ In results not shown, we also examined heterogeneous effects by SAT score of the post-HOPE dummy on the probability of an earned STEM major unconditional on initial major. The results are qualitatively similar to the results for initial STEM majors except that the coefficient for students with SAT math below 400 goes from insignificantly negative to insignificantly positive. The small sample size, low rates of STEM majors, and inclusion of persons with missing SAT among this group of low ability students leads to considerable noise in the estimation.

${ }^{30} \mathrm{We}$ also considered specific majors within business to explore the premise that the post-HOPE increase in business majors might be STEM majors shifting to the more mathematically oriented business majors. In results not presented we find statistically significant positive effects on MIS and finance majors, which is supportive of the shift from STEM to more technical business majors. However, we find negative effects for economics and accounting and especially large positive effects on marketing and management (probably the least technical business majors), which is contrary to the premise.

${ }^{31}$ As with high school GPA, there is concern that there has been a general upward trend in college GPAs.

${ }^{32}$ The observed increase in college GPAs could also be partially attributable to other factors besides HOPE driving an upward trend over time.

${ }^{33}$ We also explored the effects of controlling for USG institution in Tables 8 and 9; the results are qualitatively similar to the reported results and are available from the authors by request.

${ }^{34}$ Similarly, financial aid could be viewed as a transitory income shock that could lead to more current consumption oriented majors. Riegle-Crumb, King, Grodsky, and Muller (2012), using the NELS and HS\&B, find that an additional $\$ 10,000$ of real family income reduces the probability that a student will declare a physical science/engineering major by 0.2 to 0.5 percentage points. However, $\$ 10,000$ of permanent family income might have very different effects than transitory income from student financial aid. 


\section{Appendix}

Table 12 Summary counts of graduates and total enrollment for pre- and post-HOPE

\begin{tabular}{llll}
\hline & Pre-HOPE & Post-HOPE & \% Change \\
\hline A. Graduates & & & \\
Earned STEM major & 3,910 & 4,429 & 0.133 \\
Earned business major & 4,695 & 6,366 & 0.356 \\
Earned education major & 3,326 & 3,155 & -0.051 \\
Earned health major & 1,084 & 1,343 & 0.239 \\
Earned liberal arts major & 2,948 & 3,726 & 0.264 \\
Earned social science major & 3,534 & 3,883 & 0.099 \\
Total graduates & 19,497 & 22,902 & 0.175 \\
B. Enrollment & Pre-HOPE & Post-HOPE & $\%$ Change \\
Initial STEM major & 4,887 & 6,045 & 0.237 \\
Initial business major & 3,892 & 4,640 & 0.192 \\
Initial education major & 1,354 & 1,867 & 0.379 \\
Initial health major & 1,568 & 2,452 & 0.564 \\
Initial liberal arts major & 12,722 & 14,270 & 0.122 \\
Initial social science major & 2,498 & 2,530 & 0.013 \\
Initial undeclared major & 16,711 & 17,903 & 0.071 \\
Total enrollment & 43,632 & 49,707 & 0.139 \\
\hline
\end{tabular}

Table 13 USG cohort year dummy coefficients

\begin{tabular}{lll}
\hline Outcome: & Initial STEM major & STEM degree \\
\hline A. Total population & & \\
1991 cohort dummy & 0.0044 & 0.0053 \\
& $(0.0054)$ & $(0.0053)$ \\
1995 cohort dummy & -0.0084 & -0.0227 \\
& $(0.0054)$ & $(0.0053)^{* * *}$ \\
1996 cohort dummy & 0.0032 & -0.0222 \\
& $(0.0053)$ & $(0.0053)^{* * *}$ \\
B. Females & & \\
1991 cohort dummy & -0.0028 & 0.0062 \\
1995 cohort dummy & $(0.0067)$ & $(0.0062)$ \\
1996 cohort dummy & 0.0013 & -0.0091 \\
& $(0.0066)$ & $(0.0061)$ \\
C. Males & 0.0102 & -0.0082 \\
1991 cohort dummy & $(0.0065)$ & $(0.0061)$ \\
1995 cohort dummy & & \\
\hline N96 cohort dummy & 0.0130 & 0.0059 \\
& $(0.0088)$ & $(0.0092)$ \\
& -0.0184 & -0.0381 \\
& $(0.0089)^{* *}$ & $(0.0094)^{* * *}$ \\
& -0.0040 & -0.0387 \\
& $(0.0089)$ & $(0.0093)^{* * *}$ \\
\hline
\end{tabular}

Note: 1990 is the omitted based year. Other specifications correspond to columns 2 and 6 of Table 13. OLS Standard errors are in parentheses. ${ }^{* *}$ Significant at $5 \% ;{ }^{* * *}$ Significant at $1 \%$ 
Table 14 Post-HOPE effects on high school grade inflation

\begin{tabular}{lll}
\hline & $(1)$ & $(2)$ \\
\hline A. Total & All graduates & STEM graduates \\
B. Females & 0.1523 & 0.1140 \\
& $(0.0199)^{* * *}$ & $(0.0197)^{* *}$ \\
C. Males & 0.1671 & 0.1352 \\
& $(0.0206)^{* * *}$ & $(0.0169)^{* * *}$ \\
Sex, race/ethnicity dummies & 0.1341 & 0.0996 \\
High school dummies & $(0.0193)^{* * *}$ & $(0.0266)^{* *}$ \\
SAT dummies & Yes & Yes \\
High school GPA dummies & Yes & Yes \\
USG institution dummies & Yes & Yes \\
\hline
\end{tabular}

Standard errors in parentheses are clustered by high school graduation year

**Significant at $5 \%$ based on small sample t-distribution; ${ }^{* *}$ Significant at $1 \%$

Table 15 Effect of HOPE on STEM majors unconditional on degree completion

\begin{tabular}{|c|c|c|c|c|c|c|c|c|}
\hline & \multirow[t]{2}{*}{ (1) } & $(2)$ & (3) & (4) & \multirow[t]{2}{*}{ (5) } & (6) & (7) & \multirow[t]{2}{*}{ (8) } \\
\hline & & \multicolumn{3}{|c|}{ Initial major } & & \multicolumn{2}{|c|}{ Earned major } & \\
\hline \multirow[t]{3}{*}{ A. Total } & 0.0203 & 0.0004 & -0.0092 & 0.0099 & 0.0004 & -0.0125 & -0.0215 & -0.0134 \\
\hline & $(0.0058)^{* *}$ & $(0.0040)$ & $(0.0028)^{* *}$ & $(0.0010)^{* * *}$ & $(0.0026)$ & $(0.0011)^{* * *}$ & $(0.0015)^{* * *}$ & $(0.0016)^{* * *}$ \\
\hline & $\{14.8 \%\}$ & $\{0.3 \%\}$ & $\{-6.7 \%\}$ & $\{7.2 \%\}$ & $\{0.4 \%\}$ & $\{-13.9 \%\}$ & $\{-24.0 \%\}$ & $\{-15.0 \%\}$ \\
\hline \multirow[t]{3}{*}{ B. Females } & 0.0262 & 0.0114 & 0.0042 & 0.0145 & 0.0042 & -0.0064 & -0.0133 & -0.0078 \\
\hline & $(0.0044)^{* * *}$ & $(0.0042)^{*}$ & $(0.0033)$ & $(0.0026)^{* *}$ & $(0.0021)$ & $(0.0016)^{* *}$ & $(0.0015)^{* * *}$ & $(0.0005)^{* * *}$ \\
\hline & $\{27.7 \%\}$ & $\{12.0 \%\}$ & $\{4.4 \%\}$ & $\{15.3 \%\}$ & $\{7.3 \%\}$ & $\{-11.2 \%\}$ & $\{-23.2 \%\}$ & $\{-13.6 \%\}$ \\
\hline \multirow[t]{3}{*}{ C. Males } & 0.0132 & -0.0118 & -0.0221 & 0.0058 & -0.004 & -0.0195 & -0.0286 & -0.0189 \\
\hline & $(0.0100)$ & $(0.0057)$ & $(0.0046)^{* *}$ & $(0.0025)$ & $(0.0036)$ & $(0.0011)^{* * *}$ & $(0.0018)^{* * *}$ & $(0.0029)^{* * *}$ \\
\hline & $\{7.1 \%\}$ & $\{-6.3 \%\}$ & $\{-11.8 \%\}$ & $\{3.1 \%\}$ & $\{-3.1 \%\}$ & $\{-15.3 \%\}$ & $\{-22.5 \%\}$ & $\{-14.9 \%\}$ \\
\hline $\begin{array}{l}\text { Sex, race/ethnicity } \\
\text { dummies }\end{array}$ & Yes & Yes & Yes & Yes & Yes & Yes & Yes & Yes \\
\hline $\begin{array}{l}\text { High school } \\
\text { dummies }\end{array}$ & Yes & Yes & Yes & Yes & Yes & Yes & Yes & Yes \\
\hline SAT dummies & No & Yes & Yes & Yes & No & Yes & Yes & Yes \\
\hline $\begin{array}{l}\text { High school GPA } \\
\text { dummies }\end{array}$ & No & No & Yes & Yes & No & No & Yes & Yes \\
\hline $\begin{array}{l}\text { USG institution } \\
\text { dummies }\end{array}$ & No & No & No & Yes & No & No & No & Yes \\
\hline
\end{tabular}

Standard errors in parentheses are clustered by high school graduation year. The percent change, i.e., the coefficient divided by the mean, are shown in braces

*Significant at $10 \%$ based on small sample t-distribution; ${ }^{*}$ Significant at $5 \%$; ${ }^{* * *}$ Significant at $1 \%$ 
Table 16 Time-diff and DD effects of HOPE at Georgia Tech and University of Georgia

\begin{tabular}{lll}
\hline & $(1)$ & $(2)$ \\
& Time-difference for residents & DD using non-residents \\
\hline A. Total & -0.0742 & -0.0448 \\
& $(0.0080)^{* * *}$ & $(0.0169)^{*}$ \\
B. Females & -0.0616 & -0.0896 \\
& $(0.0123)^{* *}$ & $(0.0249)^{* *}$ \\
C. Males & -0.0828 & -0.0246 \\
& $(0.0104)^{* * *}$ & $(0.0160)$ \\
Sex, race/ethnicity dummies & Yes & Yes \\
High school dummies & Yes & Yes \\
SAT dummies & Yes & Yes \\
High school GPA dummies & No & No \\
USG institution dummies & No & No \\
\hline
\end{tabular}

Standard errors in parentheses are clustered by high school graduation year

*Significant at $10 \%$ based on small sample $t$-distribution; ${ }^{*}$ Significant at $5 \%$; ${ }^{* *}$ Significant at $1 \%$

Table 17 DD effects of HOPE using the ACS

\begin{tabular}{lll}
\hline$(1)$ & $(2)$ & $(3)$ \\
4-year window & 5-year window & 6-year window \\
\hline-0.019 & -0.018 & -0.012 \\
$(0.013)$ & $(0.010)$ & $(0.010)$ \\
\hline
\end{tabular}

Notes: Standard errors are clustered by year age 18. Regression controls include dummies for yearage18, survey year, age, birth state, sex, race, and ethnicity. The control group includes persons born in states not adopting a merit aid program prior to 1998. An X-Year Window means that cohorts included were age $18 \mathrm{X}$ years before or after the policy was adopted

\section{Competing interests}

The IZA Journal of Labor Economics is committed to the IZA Guiding Principles of Research Integrity. The authors declare that they have observed these principles.

\section{Acknowledgments}

We thank Rob Watts from the Georgia Board of Regents for his assistance in providing data, Lakshmi Pandey for technical assistance, and Peter Arcidiacono, Pierre Cahuc, Celeste Carruthers, Chris Cornwell, Julie Cullen, Bill Even, Barry Hirsch, Larry Katz, two anonymous referees, seminar participants at Miami University and Georgia State University, and session participants at the 2013 Southern Economic Association Annual Meetings for helpful comments. The data from the University System of Georgia were provided under a confidential agreement, and thus we cannot make them available; researchers interested in acquiring these data should contact the Georgia Board of Regents. Responsible editor: Pierre Cahuc.

\section{Author details}

${ }^{1}$ Andrew Young School of Policy Studies, Georgia State University, 14 Marietta St, Atlanta, GA 30303, USA. ${ }^{2}$ Spears School of Business, Oklahoma State University, 331 Business Building, Stillwater, OK 74078-4011, USA. ${ }^{3}$ IZA, Bonn, Germany.

Received: 12 May 2015 Accepted: 21 July 2015

Published online: 10 August 2015

\section{References}

Arcidiacono P (2004) Ability sorting and the returns to college major. J Econometrics 121(1-2):343-375

Arcidiacono P, Aucejo EM, Hotz VJ (2013) University differences in the graduation of minorities in STEM fields: Evidence from California. National Bureau of Economic Research Working Paper No. 18799

Arcidiacono P, Hotz VJ, Kang S (2012) Modeling college major choices using elicited measures of expectations and counterfactuals. J Econometrics 166(1):3-16 
Beffy M, Fougere D, Maurel A (2012) Choosing the field of study in post-secondary education: Do expected earnings matter? Rev Econ Stat 94(1):334-347

Berger M (1988) Predicted future earnings and choice of college major. Ind Labor Relat Rev 41(3):418-29

Carruthers, CK, Ozek U (2012) Losing HOPE: Financial aid and the line between college and work. Working Paper, University of Tennessee.

Castleman B L (2012) All or nothing: The impact of partial vs. full merit scholarships on college entry and success. Working Paper, Harvard University.

Cornwell CM, Lee KH, Mustard DB (2005) Student responses to merit scholarship retention rules. J Human Resour 40(4):895-917

Cornwell CM, Lee KH, Mustard DB (2008) The effects of state-sponsored merit scholarships on course selection and major choice in college. Working Paper, University of Georgia.

Cornwell C, Mustard DB, Sridhar D (2006) The enrollment effects of merit-based financial aid: Evidence from Georgia's HOPE program. J Labor Econ 24(4):761-86

Crisp G, Nora A, Taggart A (2009) Student characteristics, pre-college, college, and environmental factors as predictors of majoring in and earning a STEM degree: An analysis of students attending a Hispanic serving institution. American Education Research Journal 46(4):924-942

Dee TS, Jackson LA (1999) Who loses HOPE? Attrition from Georgia's college scholarship program. Southern Econ J 66(2):379-390

Delaney JA (2007) The academic consequences of state merit aid: The case of Kentucky. Ph.D. Dissertation, School of Education, Stanford University

Denning JT, Turley P (2013) Was that SMART? Institutional financial incentives and field of study. Working paper, Department of Economics, University of Texas at Austin

Donald SG, Lang K (2007) Inference with difference-in-differences and other panel data. Rev Econ Stat 89(2):221-233

Dynarski S (2000) Hope for whom? Financial aid for the middle class and its impact on college attendance. National Tax Journal Part 2 53(3):629-61

Griffith A (2010) Persistence of women and minorities in STEM field majors: Is it the school that matters? Econ Educ Rev 29(6):911-922

Henry GT, Rubenstein R (2002) Paying for grades: Impact of merit-based financial aid on educational quality. J Policy Anal Manage 21(1):93-109

Jaquette O, Curs BR, Posselt JR (2014) Tuition rich, mission poor: Nonresident enrollment and the changing proportions of low-income and underrepresented minority students at public research universities. University of Missouri Working Paper

Kinsler J, Pavan R (2011) Family income and higher education choices: The importance of accounting for college quality. J Human Capital 5(4):453-477

Kinsler J, Pavan R (2013) The specificity of general human capital: Evidence from college major choice. Working Paper, Department of Economics, University of Rochester.

Luppino M, Sander R (2015) College major peer effects and attrition from the sciences. IZA J Labor Econ 4(4):1-23

Montmarquette C, Cannings K, Mahseredjian S (2002) How do young people choose college majors? Econ Educ Rev 21(6):543-556

Moore CD (2014) Socioeconomic stratification in the STEM pathway from college to the labor market. Ph.D. Dissertation, University of Texas at Austin

Ost B (2010) The role of peers and grades in determining major persistence in the sciences. Econ Educ Rev 29(6):923-934

Pallais A (2015) Small differences that matter: Mistakes in applying to college. J Labor Econ 33(2):493-520.

Price J (2010) The effect of instructor race and gender on student persistence in STEM fields. Econ Educ Rev 29(6):901-910

Rask K (2010) Attrition in STEM fields at a liberal arts college: The importance of grades and pre-collegiate preferences. Econ Educ Rev 29(6):892-900

Riegle-Crumb C, King B, Grodsky E, Muller C (2012) The more things change, the more they stay the same? Prior achievement fails to explain gender inequality in entry into STEM college majors over time. American Educational Research Journal 49(6):1048-1073

Rothstein J, Rouse C (2011) Constrained after college: Student loans and early-career occupational choices. J Public Econ 95:149-163

Sjoquist DL, Walker MB (2010) Informing lottery budget decisions: HOPE and Pre-K. FRC Report 215, Atlanta, GA: Fiscal Research Center, Andrew Young School of Policy Studies, Georgia State University

Sjoquist DL, Winters JV (2012) Building the stock of college-educated labor revisited. J Hum Resour 47(1):270-285

Sjoquist DL, Winters JV (2013) The effects of HOPE on post-college retention in the Georgia workforce. Regional Science and Urban Economics 43(3):479-490

Sjoquist DL, Winters JV (2014) Merit aid and post-college retention in the state. Journal of Urban Economics 80(1):39-50

Sjoquist DL, Winters JV (2015) State merit-based financial aid programs and college attainment. Journal of Regional Science 55(3):364-390

Sjoquist DL, Winters JV (Forthcoming) State merit-aid programs and college major: A focus on STEM. J Labor Econ

Stange K (2013) The effect of differential pricing on undergraduate degree production by field. National Bureau of Economic Research Working Paper No. 19183

Stater M (2011) Financial aid, student background, and the choice of first-year college major. Eastern Economic Journal 37(3):321-343

Stinebrickner TR, Stinebrickner R (2014) A major in science? Initial beliefs and final outcomes for college major and dropout. Review of Economic Studies 81(1):426-472

Wang X (2012) Modeling student choice of STEM fields of study: Testing a conceptual framework of motivation, high school learning, and postsecondary context of support. Working paper, Wisconsin Center for the Advancement of Postsecondary Education, University of Wisconsin—Madison, Madison, WI 
Webber DA (2012) Expenditures and postsecondary graduation: An investigation using individual-level data from the state of Ohio. Econ Educ Rev 31:615-618

Welch JG (2014) HOPE for community college students: The impact of merit aid on persistence, graduation, and earnings. Econ of Educ Rev 43:1-20

Winters JV (2014a) STEM graduates, human capital externalities, and wages in the US. Regional Science and Urban Economics 48:190-198

Winters JV (2014b) Foreign and native-born STEM graduates and innovation intensity in the United States. IZA Discus Paper No. 8575

Wiswall M, Zafar B (2011) Determinants of college major choice: Identification using an information experiment. Staff report no. 500, Federal Reserve Bank of New York, New York, NY

Zhang L (2011) Does merit-based aid affect degree production in STEM fields: Evidence from Georgia and Florida. Journal of Higher Education 82(4):389-415

Submit your manuscript to a SpringerOpen ${ }^{\circ}$ journal and benefit from:

- Convenient online submission

- Rigorous peer review

- Immediate publication on acceptance

- Open access: articles freely available online

- High visibility within the field

Retaining the copyright to your article

Submit your next manuscript at $\boldsymbol{\sim}$ springeropen.com 